\title{
THE CHALLENGE OF HIV/AIDS TO CHRISTIAN THEOLOGY ${ }^{1}$
}

\author{
Archbishop Njongonkulu Ndungane \\ Church of the Province of Southern Africa
}

\begin{abstract}
In this article Archbishop Ndungane reflects on various aspects related to the challenge that HIV/Aids poses to the church in South Africa and to Christian theology. He draws on biblical motifs to address a wide range of issues such as stigma, gender, youth, children, suffering, healing death, funerals and the availability of resources to address the pandemic.
\end{abstract}

Key Concepts: HIV, Aids, sin, stigma

\section{Introduction}

The Psalmist says "Where can I go from your spirit? Or where can I flee from your presence? If I ascend to heaven, you are there; if I make my bed in Sheol, you are there. If I take the wings of the morning and settle at the farthest limits of the sea, even there your hand shall lead me, and your right hand shall hold me fast." (Ps 139:6-9). ${ }^{2}$ There is no part of human life or activity that is beyond God's concern, or his redemptive love. He touches every part of life. This is my starting point, not least because it is increasingly the case that there is no part of life which HIV/Aids does not touch.

\section{A Comprehensive Challenge Requires a Comprehensive Theology}

The UN Secretary General, Kofi Annan, said something similar at the Bangkok International Aids Conference in July 2004. He expressed disappointment that so many government delegations were headed and staffed almost exclusively from Health Ministries, whereas our response to the pandemic must involve everyone, across all government departments, working with civil society, at international, national and local levels. It demands a fully integrated response. ${ }^{3}$

Likewise, the challenge to theology comes at every level, in every aspect of life. It also demands a fully integrated theological response. Yet the starting point for these responses is fundamentally different. For Christians, for the church, all theology begins of course with God, and our experience of who God is, revealed in his unrestrained, abundant love. For me, this is expressed in the following passage from Romans 5, to which I am drawn again and again:

For while we were still weak, at the right time Christ died for the ungodly... God proves his love for us in that while we were still sinners, Christ died for us. Much more surely

1 This article is based on a keynote address delivered at a conference on "The challenge of HIV/Aids to Christian theology", held at the University of the Western Cape on 30 July 2004. The paper was delivered by Rev Sarah Rowling-Jones on behalf of Archbishop Ndungane who was ill at that time.

2 All Bible references taken from the New Revised Standard Version (Anglicized Edition) unless otherwise noted.

http://www.un.org/News/Press/docs/2004/sgsm9418.doc.htm 
then, now that we have been justified by his blood, will we be saved through him from the wrath of God. For if while we were enemies, we were reconciled to God though the death of his Son, much more surely, having been reconciled, will we be saved by his life. But more than that, we even boast in God through our Lord Jesus Christ, through whom we have now received reconciliation (Rom 5:6-11).

Jesus Christ died for us while we were still sinners, still enemies. We are called and redeemed and shaped and sent by his totally unwarranted sacrificial love. "Love one another as I have loved you" he commands us. This self-giving love must underlie not just our approach to HIV/Aids, but every aspect of our lives, our theology and our praxis. Jesus did not ask "What is in it for me? What do I stand to lose if I don't put myself out for these people?"

We know that the consequences for the world will be increasingly dire if there is not an exceptional response to this exceptional crisis. But this is not the motivation for Christians, nor does it shape the way we act. The challenge of HIV/Aids to our theology is the contextualisation of this gospel, of an outrageously generous God, who so loved the world that he gave, without any expectation or guarantee of receiving anything back. He loved, and he gave. As we follow his lead, loving and giving, we are likely to find ourselves drawing more deeply than ever before on the wells of God's compassion. Yet we have confidence in his promise that he will "equip us with everything good for doing his will and working in us what is pleasing to him" (Heb 13:21). ${ }^{4}$

It has been said the church is the only society that exists primarily for its non-members. Well perhaps we are not entirely unique. But we must remember that so much of Jesus' own ministry was directed to those on the margins of society - the poor, the excluded, disreputable sinners. HIV/Aids hits the poor hardest of all. It is also a disease that too often marginalises and excludes, not least because of its associations with sex. The church must take much of the blame for the issue of stigmatisation, and its attendant problems of fear, denial and silence. Christianity has too often espoused a destructive theology that links sex and sin and guilt and punishment. We must take the lead in overturning these distortions.

\section{Sin and Stigma}

The story of the blind beggar, in John 9, is a powerful illustration for us. "Rabbi," ask the disciples. "Who sinned, this man or his parents, that he was born blind?" The disciples were clear - as far as they were concerned, if this man had been born blind, then it was somebody's fault. Someone was guilty of sin, and this man's suffering in poverty was the due consequence. That was what everyone thought then. It is easy to understand why people can think the same today. For centuries the church has taught "sin, and God will punish you." Given the deep difficulties the church has always had speaking about, and dealing with, sex and morality, it is not surprising that this simple analysis hold so much sway over the lives of people in relation to HIV/Aids.

Jesus turns this way of thinking on its head. He contradicts the conventional wisdom and morality of his day. "Neither this man nor his parents sinned," he answers the disciples. "He was born blind so that God's works might be revealed in him." With this statement he sets in motion a chain of events involving the healing of the man - not just physically so that, for the first time in his life, he can see; but profoundly and psychologically, so he is able to stand his ground against those who want him to remain marked an outcast - blind

4 This quotation is from the New International Version of the Bible. 
beggar, suffering the due punishment of sin. He refutes the label of sinner, which Jesus has removed from him.

Let us follow what happens. Everyone knows this man, blind from birth. Everyone sees his condition as the just consequence of someone's sin: his own (yet how can an unborn child have sinned?), or, more likely, his parents'. He is trapped in poverty, reduced to begging. Despised, ostracised, marked out - in short, stigmatised. Jesus heals him. Those around him cannot believe it is the same man. "It is someone like him," they say. "I am the man!" he boldly insists. Yet even he is not sure how the healing has come about, or what it means. He is hauled before the Pharisees. We see a remarkable transformation in him - this pariah, with no rights as a member of the community, takes on the very people who had determined his life-long fate by first judging him and then marking him with their so-called moral theology. They interrogate his parents, who are cowed - guilty by association - was it their sin? They pass the buck back to their son, "He is of age; ask him." The Pharisees are thrown into confusion by his answers to their accusations that he has been healed by a sinner who cures on the Sabbath. The exchange is rather humorous as the man gets the upper hand over the religious experts. Aware that they cannot face the truth, he sarcastically asks if they too want to be Jesus' disciples! They cannot bear his answers, "You were born entirely in sins, and are you trying to teach us?" And they throw him out. Jesus finds the man, and tells him who he is, the Son of Man. The man believes. Jesus explains: "I came into this world for judgement so that those who do not see may see, and those who do see may become blind."

Those who see HIV/Aids as a punishment from God stand under the judgement of the Son of Man. All those who "walk by on the other side", thinking that people bring it on themselves and judging that therefore they have only themselves to blame, need to hear the danger of God's greater judgement. The church must not allow people to be marked out, labelled, categorised and judged, whether because of their own HIV infection, or the infection of family members, or poverty, or blindness or anything else. Spiritual blindness which gives rise to unnecessary suffering and which denies the full humanity of every human being is sin.

Stigma has become the silent killer - it decimates families, who cannot speak to each other about the illness in their midst. It brings fear of alienation and rejection. People shun testing and even exclude themselves from treatment, since this would give the game away. So, often unwittingly, they continue to spread infection. We must break the silence and end the stigma. I do not think that Jesus knew the meaning of the word "Taboo"! The church must also speak out the truth, which sets people free.

\section{HIV/Aids and Women - and men}

Another tragic and shameful area of the church's spiritual blindness is in relation to women, and this too is having devastating consequences in relation to HIV/Aids. Among 15-24 year olds in Sub-Saharan Africa, some three quarters of those infected are women. In some countries, the most high risk group is married women - most of whom seem to be faithful wives. It is a fact of physiology that the female body is more susceptible to infection. It is also a fact that men are physically stronger. But we let men use their strength to the detriment of women. Christianity has been complicit in sustaining the patriarchal dominance of men and the subjugation of women in terms of politics, economics, culture, society and the family as well as within the institutional church. 
So often in Scripture, in both Testaments, the position of women is ahead of that in surrounding cultures. Yet we have become rooted in millennia-old patriarchal attitudes. Failure to recognise that forward trajectory of grace is poor hermeneutics and bad exegesis - it is a distortion of the promises of God.

Jesus was particularly subversive of the role and status of women in his own time. $\mathrm{He}$ called women as herald (his mother points to his public ministry at the wedding at Cana); as evangelist (the Samaritan woman at the well is commissioned to spread the good news); as disciples (Martha makes the great proclamation of faith, responding, "Yes Lord, I believe you are the Messiah, the Son of God," when Jesus says "I am the resurrection and the life," and Mary pre-figures Jesus' washing of the disciples feet, by anointing Jesus' feet with perfume); and then Mary Magdalene encounters the truth of the resurrection and becomes the "apostle to the apostles."

Just as Jesus did, the church must accord to women dignity and status that is no less than that of men. To do this, we must not let HIV/Aids become a "women's issue' because for women, the issue here is "men"! It is therefore not just a matter of targeting policies on women. We must certainly affirm women, demonstrating that they are worthy of respect. We must also teach men and boys to respect women. Right attitudes will lay the foundations for right behaviour. We say, "Your body is a temple of the Holy Spirit - God respects you. Treat yourself with respect." We must also say "That girl, that boy, that man, that woman, their body is a temple of the Holy Spirit - treat them with equal respect." It is not enough to tell people "Say No." We must give them the ability to do so: and not just the words. We must also teach those they are with to hear "No" for what it is. We must demonstrate by example holiness of life.

We must also support the use of condoms as part of our overall strategy. It is a matter of saving lives, not preventing lives. Some recent studies suggest that teaching about condoms and making them available does not, as some fear, promote promiscuity among teenagers, but has the reverse effect. Where one member of a couple is infected, condom use must be encouraged. Yet we also recognise the difficult position of wives who suspect their husbands stray, for whom abstinence is not an option and use of condoms perhaps not negotiable.

\section{Young People}

It is certainly a challenge for the Church to deal honestly and sensibly with sex! We have not been good at it - but then, neither has the rest of society! It is often most difficult to talk about sex with young people, yet we must do so, because this is a youth-driven pandemic.

Faith communities have many programmes for young people. In Sunday school and confirmation classes and youth activities, we must give sensible, holistic teaching which helps them negotiate their transition into adulthood. Sexuality, gender issues, faithful committed relationships mirroring the covenant love of God - these must all be presented as an integral part of our teaching about growing and maturing in the Christian life. We who are followers of the Word-become-Flesh must not despise our physical bodies.

Our objective as we raise young people is nothing less than a generation without Aids. It is a disease that is preventable. We can stop its spread, and we must stop its spread. This is our primary goal - and it is a realisable one. And alongside this we strive for quality and quantity of life for those already infected and affected. We need treatment for all - in practice and not just theory. We share the attitude of "living with Aids" not "dying of Aids." Jesus came to be our Saviour and to bring us life in all its fullness, whatever our 
circumstances. The Hebrew word for salvation is linked to concepts of liberty, free from all that diminishes, demeans, oppresses, or ostracises; free from stigma and second-class citizenship. That is the gospel message.

\section{The Plight of Children}

Jesus overturned social convention in his attitude to children - indignant when the disciples rebuked people for letting their children "distract" him. "Let the little children come to me; do not stop them," he said, his generous arms of love stretched wide. (Mk 10:13ff)

The plight of affected children and its long term consequences are already almost beyond imagining. Throughout the world, there are at least 14 million children who have lost one or both parents to Aids and $95 \%$ of these are in Africa. The number is predicted to reach 25 million by $2010 .^{5}$ Children suffer first when their parents are ill. When breadwinners can no longer work, and health costs rise, expenditure on food, let alone "luxuries" like education, is constrained. Children - especially girls - drop out of school, become primary carers and scavenge for work. And after death, what happens? Orphaned and traumatised, they may be left in the care of some other relative - a widowed grandmother, themselves burdened with grief at perhaps yet another loss of an adult child, frail with age, themselves already the poorest sector of society. Sometimes there is no granny. We know far too little about the numbers of orphan headed households. They are the hardest for government to monitor and assist. Often without shelter, vulnerable to every sort of exploitation - their plight is heartbreaking.

It is also potentially devastating for the future. We already have a continent where too many children are caught up into militias. The potential for the widespread collapse of stable, productive, society is appalling to contemplate. Even where this does not happen, what chance do children who have never known stable homes, effective parenting and lifelong committed relationships have of building for themselves something they had never seen? How shall we open our arms wide with love towards these children? The Bible repeatedly tells us that the people of God have a special burden of care towards poor widows and orphans. Much is being done, but I sometimes fear we have hardly begun to fathom what this might mean. Yet Christ's embrace is big enough for us all.

\section{Dignity in Suffering}

The gospels often speak of how Jesus was "filled with compassion" - for hungry crowds, for the sick and suffering. It is Christ's overflowing compassion which we too have received, and with which we are clothed. Remembering this helps us avoid falling into patronising attitudes towards those we might consider "worse off than ourselves." Our garment of compassion is woven through with humility, and we look on others with respect, honouring their dignity as bearers of the image of God. Paul tells the Philippians, "in humility regard others as better than yourselves" (Phil 2:3). Jesus washed the feet of his disciples and said, "You also ought to wash one another's feet. I have set you an example, that you should do as I have done to you" (John 13:14,15).

Compassion is not a one way street. It is not something the rich and strong offer to the poor and weak who have no option but to accept and be grateful. It is something to be shared with one another, given and received. The letter to the Ephesians tells us, "Be kind and compassionate to one another, forgiving one another, just as in Christ, God forgave

http://www.worldvision.org/worldvision/pr.nsf/stable/barcelona_9 
you" (Eph 4:32). In Christ, everyone is deserving of our compassion. No-one is outside its scope. We must not look down on those who suffer. That too is a form of stigmatisation, of "them and us." Christ walked alongside us, sharing fully in our humanity. We walk together, in our shared humanity.

Nor must we allow ourselves to fall into a sort of "reverse stigmatisation" that falsely elevates those who suffer. Suffering is not of itself noble. Nor is poverty. But in Jesus Christ, through the cross, God made himself vulnerable to suffering. He knows what it is like to suffer. He can empathise with us. He is alongside us and he weeps with us. We are not alone.

\section{Suffering and Healing}

There is more - God works in suffering, sometimes bringing forth unexpected experiences of love and grace. This is not to say that "because God will work for good in it, suffering doesn't matter." No, the risen Christ still bore the scars of his crucifixion. God acknowledges what those who suffer, face - his compassion accords them a human dignity when physical dignity may be escaping them. The church declares that everyone deserves dignity and respect.

God heals physically - we know this - and sometimes in inexplicable ways, and sometimes God does not. But there are some who teach that "if you have faith you will be healed" - and that if you are not healed miraculously, you lack faith. Some even teach that to resort to doctors is a failure of faith. This gnosticism is not authentic Christianity.

\section{Facing our Mortality}

Jesus too was stigmatised. He was marked as an impostor, a dangerous threat to the religious authorities of his day. He consorted with sinners and broke the Sabbath. For this he was judged, and condemned, and punished with crucifixion. He faced death as an outcast from respectable society, his body bearing the marks of the cross, demonstrating that he "deserved" the death of a common criminal. The limitless love of Jesus took him not just through human life, but through the ultimate human experience of death. Secular and secularised society has a problem with death. We have distanced ourselves from it as a normal, integral, part of human life. But the church, the body of Christ, is in the business of life and death.

Christians must help recapture the concept of a "good death", a "perfect end." As the litany says, "from dying unprepared, good Lord, deliver us." To die at peace is one of the greatest gifts anyone can have. Remember how many times the risen Christ's first words to those he encounters are, "Peace be with you" and "Do not be afraid" - this is the resurrection message of the one who has passed through death. It is a message of love to those who are dying, and to those who care for them, and indeed to every one of us. With Christ beside us we can look our mortality in the eye, and know that in him we have the victory.

No-one should face death alone, uncared for, in pain, or afraid. Sometimes carers, even medical professionals, can become overwhelmed when it seems "nothing more can be done." They can feel a failure, lose hope, give up, and turn their backs, metaphorically or even literally. Of course in some places care of the dying is well developed - but medical training in this field must become more widespread, and it is up to the church to help. And in practical terms, we know much can be done to make people more comfortable - no-one 
needs to suffer pain. The frightening loss of sight, the stench of open sores - these can be alleviated, and often avoided.

We believe in the dignity of all human life - there is never "nothing more that can be done" in terms of giving care and treating with dignity and tenderness every child of God.

\section{Funerals}

Funerals are another issue. Lavish funerals, which seem to have become the norm, can place unbearable financial strains on families already over-stretched by the burden of health costs - especially where more than one family member is affected. Clergy especially must take a lead in teaching that a simple, low-cost, funeral dishonours neither the deceased nor our God.

\section{God's Generosity and His Resources}

When we make God's overwhelming generosity towards us our starting point, we are challenged in our understanding of the world's, and our own resources. "All things come from you, and of your own have we given you," prayed David (1 Chron 29:14). The Acts of the Apostles tell how the early church sold their possessions to give to those in need. The Bible is full of injunctions to deal generously with the poor. When Jesus sends out the disciples, he says "Freely you have received, freely give" and tells them not to put their trust in holding on to material resources - "take no gold, or silver, or copper" (Matt $\left.10: 8,10^{6}\right)$.

The pandemic is an exceptional crisis. We need an exceptional response, which will include a massive rise in commitment, across the globe and at every level, and a massive rise in resources. The world can afford to deal comprehensively with poverty, which provides a fertile breeding ground for the pandemic like no other. It can afford to give us the resources we need. We know that the world spends well over a trillion US dollars annually on arms. ${ }^{7}$ It is a mind-boggling sum. And when you think of the basic needs of the world's population and what little in comparison that it would take to meet them, it is shameful. We do not even have access to primary schooling for every child. Comprehensive global primary education for every child, for a year would, I am told, cost less than the world spends on armaments in four days. ${ }^{8}$ We are increasingly a "knowledge-based" world and it is a crime against humanity that people should be excluded and in consequence inevitably trapped in poverty - and when I say people, again it is girls who are most affected. Yet it is completely unnecessary.

God provides for our needs, and not for our greed. We know these things, but we most certainly need God's grace "to will and to do that which we know to be his will." The world needs a new way of looking at creation - responsible stewards know that all our resources are bountiful gifts of the generous creator. They are there to be shared with that same generosity and open-handedness, to be used for the common good, for ourselves and those who come after us. Short term consumerism and aid narrowly tied to donor interests, is not holistic, and is not holy.

New International Version.

http://web.worldbank.org/WBSITE/EXTERNAL/NEWS/0,,contentMDK:20172632 menuPK:34472 pagePK: 34370 piPK:34424 theSitePK:4607,00.html

http://www.blackwell-synergy.com/links/doi/10.1111/j.1467-7660.2004.00340.x/abs/ 


\section{Some Conclusions}

When I became Archbishop, I never imagined the breadth of ministry that would develop, especially on the international stage, where my portfolio as the lead Anglican Primate on matters of HIV/Aids and international trade and debt, has opened many doors. Wherever I go - when I fly to the "farthest limits of the sea", as the Psalmist would have it - I pray that I may take whatever opportunities present themselves to bring Christ's message of love and hope. Please keep me in your prayers.

I am delighted that there is a growing awareness of the vital, often unique, role that faith communities can play in facing the pandemic. At Bangkok, UNAids executive director Peter Piot said "Political systems come and go, politicians, businesses and UN organizations come and go, but the long-term perspective, the memory and the future is with faith-based organizations and religions ... that perspective is what has been missing in our response to the Aids epidemic." "I see this not just as an invitation to be effective partners on the ground, but also as a challenge to bring the prophetic voice of the church in every situation and circumstance.

We need academic theologians to help us sift through scripture and tradition, sensitive to culture and context, aware of the best in contemporary scholarship. We must tease out what will best guide our lives today, incorporate it in our training, and communicate it clearly in ways that help people live their lives. We must challenge society, governments and the world!

I am optimistic that his Word will not return empty, but will bear fruit. Slowly things are moving in a better direction, and with increasing speed, though we must never underestimate the urgency of what is before us, and we are still moving far too slowly. As Psalm 139 reminds us, God is bigger than HIV/Aids - in every sense. He is more powerful than HIV/Aids. And our life with him encompasses far more than our response to HIV/Aids. It is important to stress that, and not think that all of Christian theology and faith must come through the prism of this disease.

Nevertheless, if we fail to rise to the challenges of this pandemic, it will be the greatest disaster that the human race has known. I do not think that this is to overstate the risks. For myself, it seems that God has brought me to this time and place where I have particular opportunities to speak out, and it is my duty to use them. So much of my ministry and life is shaped by experiences of the enormity of God's overflowing, abundant grace. The generosity of his love is overwhelming. Expecting nothing from us, he rescues us from sin and death. He calls to us, "Choose life". Our response must be to help others also, to "choose life."

Ecumenical News Service Report: ENI-04-0429, 040712. 